\title{
Factors affecting the quality of boar semen stored by means of dialysis
}

\author{
K. Bamba and M. Sone* \\ Faculty of Agriculture, Shizuoka University, Shizuoka 422, and \\ *Shizuoka Prefectural Swine Research Station, Hamakita 434, Japan
}

\begin{abstract}
Summary. The effects of dialysis fluids containing blood serum, serum albumin or activated charcoal on the storage of boar semen were examined. The effects of antibiotics were also tested by including them in the dialysis fluids and semen samples. Undiluted semen was stored for 7 days at $15^{\circ} \mathrm{C}$ by means of dialysis across a cellulose membrane. A combination of sulbenicillin and streptomycin was superior to that of penicillin and streptomycin in reducing bacteria and maintaining sperm motility and normal acrosomes. Serum albumin exerted a beneficial effect on the stored spermatozoa which may be due to its capacity to adsorb the metabolic products from bacteria and spermatozoa; it could be replaced with activated charcoal.
\end{abstract}

\section{Introduction}

It has been shown that sperm motility and normal acrosome morphology are maintained for up to 7 days by dialysing undiluted boar semen against a solution containing pig blood serum (Bamba, Sone \& Takeda, 1979). However, the use of blood serum is not practical because it is difficult to prepare and store under field conditions. The object of the present study was therefore to examine the mode of action of serum and, if possible, find a chemically stable substitute for it, or effective antibiotics.

\section{Materials and Methods}

Semen was collected manually from mature boars and the sperm-rich fraction was used for the experiments. Immediately after collection, antibiotics were added to the semen sample in the same concentrations as those in the dialysis fluid. The basic dialysis fluid consisted of 3 parts of Krebs-Ringer-bicarbonate $\left(118.5 \mathrm{mM}-\mathrm{NaCl}, 4.7 \mathrm{~mm}-\mathrm{KCl}, 2.5 \mathrm{~mm}-\mathrm{CaCl}_{2}, 1.2 \mathrm{~mm} / \mathrm{KH}_{2} \mathrm{PO}_{4}\right.$, $1.2 \mathrm{~mm}-\mathrm{MgSO}_{4}, 24.9 \mathrm{~mm}-\mathrm{NaHCO}_{3}$, gas with $\mathrm{CO}_{2}$ for $\left.1 \mathrm{~h}\right)$ and one part of $5.05 \%(\mathrm{w} / \mathrm{v})$ glucose solution (referred as KG31).

The semen $(5 \mathrm{ml})$ was placed in cellulose tubing (Visking, 24/32, length $10 \mathrm{~cm}$ ) at room temperature $\left(25-30^{\circ} \mathrm{C}\right)$ and then immersed in the dialysis fluid $(20 \mathrm{ml})$ in a plastic bag $(4 \times 12$ $\mathrm{cm})$. The sample was cooled to $15^{\circ} \mathrm{C}$ over $2 \mathrm{~h}$ and stored for 7 days. After storage, the semen was centrifuged at $350 \mathrm{~g}$ for $15 \mathrm{~min}$ and the supernatant was discarded. The spermatozoa were resuspended in Ca-free Krebs-Ringer-phosphate (123.2 mM-NaCl, 4.9 mM-KCl, $1.2 \mathrm{~mm}-$ $\left.\mathrm{MgSO}_{4}, 16 \mathrm{~mm}-\mathrm{Na}_{2} \mathrm{HPO}_{4} \cdot 2 \mathrm{H}_{2} \mathrm{O}, 3.2 \mathrm{~mm}-\mathrm{HCl}, \mathrm{pH} 7 \cdot 4\right)$ containing $0.1 \%(\mathrm{w} / \mathrm{v})$ glucose. The suspension was incubated at $37^{\circ} \mathrm{C}$ for $1 \mathrm{~h}$ and the motility and acrosomal morphology of spermatozoa were examined. The estimation of motility was made microscopically at $37^{\circ} \mathrm{C}$ by 
placing $10 \mu 1$ semen between a coverslip $(1.8 \times 1.8 \mathrm{~cm})$ and slide which was smeared with 16.6 $\mu \mathrm{g}$ anhydrous caffeine $/ \mathrm{cm}^{2}$ (Bamba \& Kojima, 1978). Acrosomal morphology was examined in smears stained with eosin-nigrosin (Dott \& Foster, 1972). In each smear examined under the light microscope at $\times 800$ magnification, 200 spermatozoa were counted and the proportion of spermatozoa with normal acrosomes was evaluated.

Bacterial counts were made on 2 pour plates prepared for each sample with nutrient agar (5 $\mathrm{g}$ broth extract, $10 \mathrm{~g}$ peptone, $15 \mathrm{~g}$ agar, $5 \mathrm{~g} \mathrm{NaCl}$ and $1 \mathrm{~g}$ glucose per litre). The plates were incubated aerobically at $37^{\circ} \mathrm{C}$ for $48 \mathrm{~h}$.

The data (all percentages were transformed to angles) were subjected to analysis of variance. Means which were significantly different were then contrasted by the method of least significant differences.

Experiment 1. This experiment was conducted to test the possibility that blood serum was acting as a kind of antibacterial agent. The dialysis fluids used were KG31 and KG31 containing $25 \%(\mathrm{v} / \mathrm{v})$ pig blood serum. Streptomycin sulphate $(1 \mathrm{mg} / \mathrm{ml}$; Meiji, Tokyo) was added to the samples (semen and dialysis fluid) in combination with penicillin potassium $\mathrm{G}$ (1000 i.u./ml; Meiji, Tokyo) or disodium sulbenicillin $(1 \mathrm{mg} / \mathrm{ml}$; Takeda, Osaka) which was shown to be superior to pencillin for both bacterial control and sperm survival in diluted boar semen (Bamba, Hashiguchi, Kojima \& Sone, 1980).

Experiment 2. This experiment was carried out to test whether albumin exerted a beneficial effect on the maintenance of motility and normal acrosomes of spermatozoa across a cellulose membrane. The effect of activated charcoal, which is used as an adsorbent of metabolic waste products in the artificial kidney, was also studied.

Serum albumin was prepared from pig blood serum by the salting-out technique; a saturated solution of ammonium sulphate was added to serum $(1: 1, v / v)$ and the precipitate formed was removed by filtration. The filtrate was saturated with solid ammonium sulphate and the $\mathrm{pH}$ of the solution was adjusted to 4.8 with $1 \mathrm{~N}^{-\mathrm{H}_{2}} \mathrm{SO}_{4}$. The solution was left overnight at $5^{\circ} \mathrm{C}$, and the precipitated albumin fraction was collected by filtration and dissolved in a small amount of water. The above treatment was repeated twice. The albumin fraction was then dialysed against distilled water until there was negligible $\mathrm{NH}_{4}{ }^{+}$(detected with Nestler's reagent) in the dialysate. Albumin was freeze dried and stored at $-25^{\circ} \mathrm{C}$.

Activated charcoal (special grade; Wako, Tokyo) was used after further purification by boiling in distilled water for $15 \mathrm{~min}$ and filtration by suction. The washing process was repeated until the anions that react with silver nitrate reagent could no longer be detected in the wash water. The purified material was then dried at $100^{\circ} \mathrm{C}$ for $24 \mathrm{~h}$ and stored in a desiccator.

Semen samples were stored by dialysing against $\mathrm{KG} 31$ solutions containing albumin $(1.0 \%$, $\mathrm{w} / \mathrm{v})$ or activated charcoal $(0.125,0.25,0.5,1.0$ or $2.0 \%, \mathrm{w} / \mathrm{v})$. As the control dialysis fluids, KG31 and KG31 containing 25\% (v/v) blood serum were used. All samples contained both streptomycin sulphate $(1 \mathrm{mg} / \mathrm{ml})$ and disodium sulbenicillin $(1 \mathrm{mg} / \mathrm{ml})$.

\section{Results}

\section{Experiment 1: effects of blood serum and antibiotics}

Eight replicate experiments ( 2 ejaculates from each of 4 boars) were carried out and the results are presented in Table 1 .

Bacterial growth in the dialysed semen was inhibited in the presence of blood serum. Sulbenicillin was better than penicillin for bacterial control. The inhibitory effect of blood serum was more noticeable in the samples containing penicillin than sulbenicillin.

The percentages of progressively motile spermatozoa and of spermatozoa with normal acrosomes were higher in the samples containing sulbenicillin than in those containing penicillin. The addition of blood serum to the dialysis fluid containing penicillin gave a slight improvement 
in the maintenance of normal acrosome morphology but had little effect when sulbenicillin was used as the antibacterial agent. Spermatozoa from some ejaculates showed very poor motility after storage, especially in the samples containing penicillin.

Table 1. Effects of blood serum and antibiotics on the quality of boar semen after storage for 7 days by dialysis

\begin{tabular}{lclcc}
\hline Antibiotics* & $\begin{array}{c}\text { Blood } \\
\text { serum }\end{array}$ & Bacterial index $\dagger$ & $\begin{array}{c}\text { Sperm motility } \\
(\%)\end{array}$ & $\begin{array}{c}\text { Normal acrosomes } \\
(\%)\end{array}$ \\
\hline SBPC + SM & - & $1.87 \pm 0 \cdot 35^{\mathrm{A}}$ & $59 \cdot 8 \pm 18 \cdot 5^{\mathrm{A}, \mathrm{B}}$ & $69 \cdot 8 \pm 11 \cdot 2^{\mathrm{A}, \mathrm{a}}$ \\
SBPC + SM & + & $1 \cdot 50 \pm 0 \cdot 53^{\mathrm{B}}$ & $59 \cdot 7 \pm 12 \cdot 1^{\mathrm{C}, \mathrm{D}}$ & $68 \cdot 5 \pm 9 \cdot 3^{\mathrm{B}, \mathrm{b}}$ \\
PCG + SM & - & $3 \cdot 37 \pm 1 \cdot 50^{\mathrm{A}, \mathrm{B}, \mathrm{a}}$ & $26 \cdot 2 \pm 20 \cdot 8^{\mathrm{A}, \mathrm{C}}$ & $41 \cdot 1 \pm 23 \cdot 9^{\mathrm{A}, \mathrm{B}}$ \\
PCG + SM & + & $2 \cdot 12 \pm 0.64^{\mathrm{a}}$ & $25 \cdot 0 \pm 18 \cdot 7^{\mathrm{B}, \mathrm{D}}$ & $48 \cdot 0 \pm 21 \cdot 8^{\mathrm{A}, \mathrm{b}}$ \\
\hline
\end{tabular}

Values are mean \pm s.d. for 8 observations; values with the same superscript letter are significantly different: ${ }^{\mathrm{A}}, \mathrm{B}, \mathrm{C}, \mathrm{D} P<0.01 ;{ }^{\mathrm{a}, \mathrm{b}} P<<0.05$.

* SBPC = sulbenicillin; PCG = penicillin G; $\mathrm{SM}=$ streptomycin. Antibiotics were included in dialysis fluid and semen.

+ Bacterial index, $n$, corresponds to $10^{n-1}-10^{n}-1$ bacteria/ml $(1=\leqslant 9 ; 2=10-99$; $3=100-999 ; 4=1000-9999$ ).

\section{Experiment 2: effects of serum albumin and activated charcoal}

Eight ejaculates ( 1 ejaculate from each of 8 boars) were used for this experiment and the results are given in Table 2 .

The addition of albumin and activated charcoal $(0 \cdot 125-1.0 \%)$ were effective in increasing both the motility and the proportion of spermatozoa having normal acrosomes. The highest motility score was obtained in the presence of $0.25 \%$ activated charcoal. The proportion of normal acrosomes was highest in the sample containing albumin, but a very similar result was obtained in the presence of $0.25 \%$ activated charcoal. Increasing the concentration of activated charcoal from 0.25 to $2.0 \%$ caused a reduction in motility and proportions of spermatozoa with normal acrosomes. The addition of blood serum had little effect on acrosome morphology and adverse effect on motility.

Table 2. Effects of albumin and activated charcoal in the dialysis fluid on boar sperm motility and acrosome morphology after storage for 7 days by dialysis

\begin{tabular}{|c|c|c|c|}
\hline Additive & $\begin{array}{l}\text { Proportion in } \\
\text { dialysis fluid }\end{array}$ & $\begin{array}{l}\text { Sperm motility } \\
(\%)\end{array}$ & $\begin{array}{c}\text { Normal acrosomes } \\
(\%)\end{array}$ \\
\hline None & & $58.6 \pm 12.3$ & $47 \cdot 3 \pm 12 \cdot 2^{\mathrm{a}, \mathrm{b}}$ \\
\hline Albumin $(w / v)$ & $1 \cdot 0$ & $64 \cdot 2 \pm 20 \cdot 0^{a}$ & $63 \cdot 2 \pm 8 \cdot 2^{a}$ \\
\hline \multirow[t]{5}{*}{ Activated charcoal (w/v) } & 0.125 & $63 \cdot 8 \pm 11 \cdot 2^{b}$ & $56 \cdot 5 \pm 12.4$ \\
\hline & 0.25 & $69 \cdot 8 \pm 6 \cdot 7^{\wedge}$ & $62.8 \pm 9.9^{b}$ \\
\hline & 0.5 & $68.0 \pm 9.0^{\mathrm{B}}$ & $57.8 \pm 9.7$ \\
\hline & $1 \cdot 0$ & $62.0 \pm 15.9$ & $56 \cdot 3 \pm 11 \cdot 0$ \\
\hline & $2 \cdot 0$ & $50 \cdot 3 \pm 19 \cdot 1$ & $50 \cdot 1 \pm 12 \cdot 5$ \\
\hline $\operatorname{Serum}(v / v)$ & $25 \cdot 0$ & $44 \cdot 8 \pm 25 \cdot 5^{A, B, a, b}$ & $50.0 \pm 16.8$ \\
\hline
\end{tabular}

Values are mean \pm s.d. for 8 observations; means with the same superscript letter are significantly different: ${ }^{\mathrm{A}, \mathrm{B}} P<0.01 ;{ }^{\mathrm{a}, \mathrm{b}} P<0.05$.

\section{Discussion}

The results of the present study suggest that blood serum exerts its beneficial effect on boar spermatozoa through at least two mechanisms. They may be attributed to some dialysable components of blood serum and albumin. The dialysable fraction showed a slight antibacterial activity and appeared to exert a favourable effect through bacterial control. Bornside, Merritt \& 
Weil (1964) observed antibacterial activity in the globulin fraction of blood serum. However, the antibacterial activity observed in this study is independent of globulin because it cannot pass through the cellulose membrane. The antibacterial activity may be due to a metabolic product such as lactic acid, but precise details of the action are unclear. In Exp. 2, dialysis fluid containing blood serum was not as effective as that containing serum albumin in the maintenance of motility and normal acrosomes of spermatozoa. This fact indicates that the dialysable fraction of blood serum has a toxic effect on spermatozoa together with the inhibitory effect on bacterial growth. The toxic effect seems to counteract the beneficial effect of blood serum when its antibacterial activity is not required in the presence of some effective antibiotics. Therefore, the addition of blood serum to the dialysis fluid is not necessary when sulbenicillin and streptomycin are included in the dialysis fluid and semen.

Bredderman \& Foote (1971) reported that BSA markedly prolonged vigorous sperm motility in artificial media. A similar effect of albumin was observed by Lindholmer (1974), Harrison, Dott \& Foster (1978), Dott, Harrison \& Foster (1979) and Suter, Chow \& Martin (1979). However, the mechanism of action of albumin on spermatozoa is still not completely elucidated. In the present study, the addition of albumin to the dialysis fluid greatly improved sperm survival, acting presumably across the cellulose membrane. The main function of albumin is its role in osmotic regulation of blood. It also has an important role in transporting various substances from one tissue to another due to its ability to dissolve substances which are sparingly soluble in water and to bind tightly the dissolved substances (White, Handler, Smith, Hill \& Lehman, 1978). A preliminary experiment showed that none of the macromolecules tested (PVP, Ficoll, dextran and sodium alginate) were effective substitutes for albumin. It therefore seems unlikely that the effect of albumin on sperm storage by dialysis is related to its osmotic regulating property. It is more probable that albumin exerts its effect by adsorbing toxic metabolic products from bacteria and spermatozoa. The fact that activated charcoal could replace albumin supports this hypothesis. On the other hand, activated charcoal suffers from the disadvantage that it adsorbs even some effective substances such as antibiotics and nutrients. Another preliminary study showed that the bacterial count in dialysed semen is increased slightly in the presence of activated charcoal in the dialysis fluid. Furthermore, the respiration and motility of washed boar spermatozoa were greatly depressed when activated charcoal $(0.25 \%)$ was directly added to the sperm suspension (KRP containing $0.1 \%$ glucose). It is therefore inadvisable to use activated charcoal as an additive to the diluent of semen, but could be added to the dialysis fluid instead of albumin because it is chemically more stable and inexpensive.

The results of the present study show that the storage period of boar spermatozoa at $15^{\circ} \mathrm{C}$ can be prolonged if certain toxic waste products are removed and bacterial proliferation is controlled.

We thank Dr C. E. Adams, A.R.C. Institute of Animal Physiology, Cambridge, for help with the manuscript, and Mrs H. Ikeda for technical assistance.

\section{References}

Bamba, K. \& Kojima, Y. (1978) Evaluation of boar sperm motility by caffeine-slide. Jap. J. Anim. Reprod. 24, 100-104.

Bamba, K., Sone, M. \& Takeda, K. (1979) Studies on the storage of undiluted boar semen by means of dialysis. Effects of various dialysis fluids on the motility and acrosome morphology of spermatozoa. Jap. J. Zootech. Sci. 50, 740-746.

Bamba, K., Hashiguchi, T., Kojima, Y. \& Sone, M. (1980) Effects of antibiotics on the storage of boar semen at $15^{\circ}$ C. Jap. J. Swine Sci. 17, 91-95.
Bornside, G.H., Merritt, C.B. \& Weil, A.C. (1964) Reversal by ferric iron of serum inhibition of respiration and growth of Bacillus subtilis. J. Bact. 87, 1443-1451.

Bredderman, P.J. \& Foote, R.H. (1971) Factors stabilizing bull sperm cell volume and prolonging motility at high dilution. Expl Cell Res. 66, 458-464.

Dott, H.M. \& Foster, G.C. (1972) A technique for studying the morphology of mammalian spermatozoa which are eosinophilic in a differential 'live/dead' stain. J. Reprod. Fert. 29, 443-445. 
Dott, H.M., Harrison, R.A.P. \& Foster, G.C.A. (1979) The maintenance of motility and the surface properties of epididymal spermatozoa from bull, rabbit and ram in homologous seminal and epididymal plasma. J. Reprod. Fert. 55, 113-124.

Harrison, R.A.P., Dott, H.M. \& Foster, G.C. (1978) Effect of ionic strength, serum albumin and other macromolecules on the maintenance of motility and the surface of mammalian spermatozoa in a simple medium. J. Reprod. Fert. 52, 65-73.

Lindholmer, Ch. (1974) The importance of seminal plasma for human sperm motility. Biol. Reprod. 10, 533-542.

Suter, D., Chow, P.Y.W. \& Martin, I.C.A. (1979) Maintenance of motility in human spermatozoa by energy derived through oxidative phosphorylation and addition of albumin. Biol. Reprod. 20, 505-510.

White, A., Handler, P., Smith, E.L., Hill, R.L. \& Lehman, I.R. (1978) Serum albumin. In Principles of Biochemistry, pp. 908-910. Eds J. D. Jeffers, A. Macnow, M. LaBarbera \& T. Armstrong. McGrawHill Kogakusha Ltd, Tokyo.

Received 26 August 1980 